\title{
Aktivitas Psikis Tokoh Utama dalam Novel Pasung Jiwa Karya Okky Madasari
}

\author{
Zulfahita $^{1}$, Susan Neni Triani ${ }^{2}$, Sari Yulistiana ${ }^{3}$ \\ Program Studi Pendidikan Bahasa dan Sastra Indonesia, STKIP Singkawang
}

Email: zulfahita@yahoo.co.id, susannenitriani@gmail.com

\author{
Keywords : \\ aktivitas psikis, tokoh utama, \\ psikologi sastra
}

\begin{abstract}
Penelitian ini dilatarbelakangi oleh ketertarikan untuk mengetahui aktivitas psikis yang terdapat dalam novel Pasung Jiwa. Adapun alasan memilih aktivitas psikis karena dengan mengetahui berbagai aktivitas psikis manusia, maka pembaca dapat melihat gambaran kejiwaan dari masing-masing tokoh yang baik dan yang buruk, tetapi tidak untuk ditiru perbuatan yang merugikan orang lain. Rumusan masalah dalam penelitian ini adalah bagaimana gejala kognitif tokoh utama, gejala afektif tokoh utama, gejala konatif tokoh utama, gejala campuran tokoh utama, dan implementasi terhadap rencana pembelajaran Bahasa dan Sastra Indonesia dalam novel Pasung Jiwa karya Okky Madasari. Tujuan dalam penelitian ini adalah pendeskripsian gejala kognitif tokoh utama, gejala afektif tokoh utama, gejala konatif tokoh utama, gejala campuran tokoh utama. Metode yang digunakan dalam penelitian ini adalah metode deskriptif. Data dalam penelitian ini adalah berupa kutipan-kutipan (kata, frasa, dan bentuk kalimat). Dari hasil analisis terhadap novel Pasung Jiwa karya Okky Madasari, maka dapat disimpulkan (1) Gejala kognitif yaitu perhatian, pengamatan, tanggapan, fantasi, ingatan, pikiran, dan intuisi. (2) Gejala afektif yaitu perasaan, affek dan stemming, suasana hati, simpati dan empati. (3) Gejala konatif yaitu refleks, kebiasaan, nafsu, keinginan, kecendrungan. (4) Implementasi terhadap pembelajaran adalah pembelajaran aktivitas psikis tokoh utama dapat diterapkan pada siswa XI dengan materi menganalisis unsurunsur ekstrinsik dan intrinsik novel Indonesia dan terjemahan dan menggunakan metode Two Stay Two Stray.
\end{abstract}




\section{PENDAHULUAN}

Karya sastra merupakan suatu bentuk dan hasil pekerjaan seni kreatif yang objeknya adalah manusia dan kehidupannya dengan menggunakan bahasa sebagai mediumnya. Sebagai seni kreatif yang menggunakan bahasa dan segala macam segi kehidupan maka tidak saja merupakan suatu media untuk menyampaikan ide, teori atau sistem berpikir, tetapi juga merupakan media untuk menampung ide, teori atau sistem berpikir manusia. Sebagai karya kreatif, sastra harus mampu melahirkan suatu kreasi yang indah dan berusaha menyalurkan kebutuhan keindahan manusia.

Satu di antara karya sastra adalah novel. Novel merupakan sebuah karya fiksi yang mengemukakan sesuatu secara lebih bebas, manyajikan sesuatu secara lebih banyak, lebih rinci, lebih detail, dan lebih banyak melibatkan berbagai permasalahan yang lebih kompleks (Nurgiantoro, 2015:13). Isi novel lebih panjang dan lebih kompleks dari isi cerpen, serta tidak ada batasan struktural dan sajak. Di dalam karya sastra novel disusun oleh dua unsur yang menyusunnya. Bagian dari unsur instrinsik adalah tokoh. Tokoh adalah individu rekaan yang mengalami peristiwa atau perlakuan dalam berbagai peristiwa dalam cerita. Tokoh cerita biasanya ditampilkan dalam suatu karya naratif, atau drama, yang oleh pembaca ditafsirkan memiliki kualitas moral dan kecendrungan tertentu seperti yang diekspresikan dalam ucapan dan apa yag dilakukan dalam tindakan. Tokoh utama dalah tokoh yang diutamakan penceritaannya dalam novel yang bersangkutan.

Tokoh yang terdapat dalam novel ini mempersoalkan aktivitas manusia, baik yang dapat diamati maupun yang tidak. Dalam diri setiap manusia, pasti melakukan aktivitas baik fisik maupun psikis. Aktivitas fisik yang dilakukan manusia akan sangat mudah untuk dilihat, tapi tidak dengan aktivitas psikis. Aktivitas psikis manusia dilakukan untuk mencapai tujuan tertentu yang diinginkan manusia yang dicerminkan dengan tingkah laku. Minderop (2013:3) menyatakan bahwa psikologi berarti ilmu jiwa atau ilmu yang menyelidiki dan mempelajari tingkah laku manusia.

Peneliti memilih novel Pasung Jiwa karena objek yang akan dikaji berhubungan dengan psikologi khususnya pada aspek aktivitas psikis. Di mana di dalam novel Pasung Jiwa ini terdapat empat macam aktivitas psikis tokoh utama di antaranya, gejala kognitif, gejala afektif, gejala konatif, dan gejala campuran. Novel Pasung Jiwa menceritakan tentang perjalanan hidup dua orang tokoh yang bernama Sasana dan Cak Jek. Novel Pasung Jiwa merupakan novel keempat karya Okky Madasari pada tahun 2013. Novel Pasung Jiwa juga sudah memiliki peminat dari masyarakat asing dengan diterbitkannya edisi Inggris dengan judul Bound dan dalam bahasa Jerman terbit tahun 2015 dengan judul Gebunden. Melalui novel ini penulis ingin mengetahui apa saja aktivitas psikis yang dialami oleh tokoh-tokoh utamanya.

Berdasarkan latar belakang di atas pelajaran bahasa Indonesia khususnya sastra dapat diajarkan kepada siswa berupa novel. Di dalam novel siswa dapat menemukan unsur instrinsik dan ekstrinsik. Dalam kaitannya dengan pembelajaran bahasa Indonesia di sekolah maka hubungan penelitian ini terdapat dalam Kurikulum Tingkat Satuan Pendidikan (KTSP) pada SMA kelas sebelas (XI) semester 1 dengan Standar Kompetensi (SK) Membaca: 7. Memahami berbagai hikayat, novel Indonesia/terjemahan. Kompetensi Dasar (KD) 7.2 Menganalisis unsur-unsur instrinsik dan unsur ekstrinsik novel Indonesia/terjemahan. Indikator dalam pembelajaran yaitu mengidentifikasi unsur-unsur instrinsik (tema, tokoh, penokohan, dan amanat) dalam novel Indonesia. Dari penjelasan di atas peneliti akan menelaah tentang aktivitas psikis tokoh utama dalam novel Pasung Jiwa karya Okky Madasari.

\section{KAJIAN TEORI}

Novel merupakan karya fiksi yang mengemukakan sesuatu secara lebih bebas, menyajikan sesuatu secara lebih banyak, lebih rinci, lebih detail, dan lebih banyak melibatkan berbagai permasalahan yang lebih kompleks (Nurgiyantoro, 2015:13). Dari pendapat tersebut novel dapat diartikan sebagai karya fiksi yang memiliki cerita lebih kompleks. Dari segi panjang cerita, novel jauh lebih panjang dari pada cerpen. Novel disajikan secara lebih rinci dengan mengemukakan sesuatu secara lebih bebas. Novel mengungkapkan konflik kehidupan para tokohnya secara lebih mendalam dan halus. Selain tokoh- 
tokoh, serangkaian peristiwa dan latar ditampilkan secara tersusun sehingga bentuknya lebih panjang dibandingkan dengan prosa rekaan yang lain (Wicaksono, 2014:116). Dalam pembicaraan sebuah cerita fiksi, sering dipergunakan istilah-istilah seperti tokoh dan penokohan, watak dan perwatakan, atau karakter dan karakterisasi secara bergantian dengan menunjuk pengertian yang hampir sama.

Ada istilah yang pengertiannya menunjuk pada tokoh cerita dan pada teknik pengembangannya dalam sebuah cerita. Istilah cerita menunjuk pada orangnya, pelaku cerita. Tokoh (penokohan) adalah orangorang yang ditampilkan dalam sesuatu karya naratif oleh pembaca ditafsirkan memiliki kualitas moral dan kecendrungan tertentu seperti yang diekspresikan dalam ucapan dan apa yang dilakukan dalam tindakan (Nurgiyantoro, 2015:490).

Dalam konsepnya, psikologi menyibukkan diri dengan masalah kegiatan psikis seperti berpikir, belajar, menanggapi, mencinta, membenci dan lain-lain. Menurut Emzir dan Rohman (2015:164) macam-macam kegiatan psikis pada umumnya digolongkan dalam empat kategori, yaitu:

a. Gejala Pengenalan atau Kognitif

Gejala kognitif ialah segenap gejala yang terdapat dalam kejiwaan sebagai hasil dari pengenalan. Sebagai contoh dari pengenalan adalah manusia bisa mendenganr suara, melihat cahaya, mengamati gerakan yang ada disekitarnya, menyimpan satu kenangan indah dan menemukan suatu kebenaran.

b. Gejala Perasaan dan Emosi atau Afektif

Gejala afektif merupakan bagian dari kegiatan psikis yang berkenaan dengan perasaan dan emosi manusia.

c. Gejala kemauan atau Konatif

Sumanto mengatakan kemauan merupakan salah satu fungsi hidup kejiwaan manusia yang dapat diartikan sebagai aktivitas psikis yang mengandung usaha aktif dan berhubungan dengan pelaksanaan suatu tujuan yang menjadi titik akhir dari gerakan yang menuju pada suatu arah. Dalam istilah sehari-hari, kemauan dapat disamakan dengan kehendak atau hasrat yang merupakan fungsi jiwa untuk dapat mencapai sesuatu. Kemauan dikelompokkan menjadi: dorongan, keinginan, hasrat, kecendrungan, hawa nafsu dan kemauan (Emzir dan Rohman, 2015:177).

d. Gejala Campuran

Gejala campuran atau yang biasa juga disebut sebagai gejala kombinasi merupakan campuran dari ketiga gejala yang telah dipaparkan sebelumnya.

Mempelajari psikologi sastra sebenarnya sama halnya dengan mempelajari manusia dari sisi dalam. Mungkin aspek dalam ini yang acap kali bersifat subjektif, yang membuat pemerhati sastra menganggapnya berat. Sesunggunhya belajar psikologi sastra amat indah, karena dapat memahami isi kedalaman jiwa manusia, jelas amat luas dan dalam. Menurut (Endraswara, 2013:96) Psikologi sastra adalah kajian sastra yang memandang karya sebagai aktivitas kejiwaan. Pengarang akan menggunakan cipta, rasa, dan karya dalam berkarya.

\section{METODE PENELITIAN}

Metode yang digunakan dalam penelitian ini adalah metode deskriptif dengan bentuk penelitian kualitatif. Moleong (2014:11) menyatakan bahwa deskriptif merupakan data yang dikumpulkan adalah berupa kata-kata, gambar, dan bukan angka-angka. Hal ini disebabkan oleh adanya penerapan metode kualitatif. Selain itu, semua yang dikumpulkan berkemungkinan menjadi kunci terhadap apa yang sudah diteliti. Menurut (Moleong, 2014:6) penelitian kualitatif merupakan penelitian yang bermaksud untuk memahami fenomena tentang apa yang dialami oleh subjek penelitian misalnya perilaku, persepsi, motivasi, tindakan, secara holistik, dan dengan cara deskripsi dalam bentuk kata-kata dan bahasa, pada suatu konteks khusus yang alamiah dan dengan memanfaatkan berbagai metode alamiah.

Dalam penelitian ini pendekatan yang digunakan adalah pendekatan psikologi sastra. Psikologi sastra adalah ilmu yang mengkaji karya sastradari sudut kejiwaan (Ratna, 2004: 340). Psikologi sastra tidak bermaksud untuk memecahkan masalah psikologis praktis seperti kejiwaan manusia. Namun 
memahami aspek-aspek kejiwaan yang terkandung dalam suatu karya sastra. Penelitian ini menggunakan pendekatan psikologi sastra berarti menganalisis tentang aktivitas psikis atau kejiwaan yang dialami oleh tokoh utama dalam novel Pasung Jiwa karya Okky Madasari. Teknik pengumpul data yang penulis gunakan untuk memperoleh data dan informasi mengenai novel Pasung Jiwa yaitu dengan melakukan studi dokumenter dengan instrumen penelitian utama ialah peneliti. Sedangkan alat yang digunakan adalah peneliti sebagai instrumen kunci berkedudukan sebagai perencana, pelaksana, penganalisis, dan penafsir data penelitian. Selain peneliti sebagai instrumen, alat pengumpul data yang digunakan yaitu kertas pencatat data yang berisi catatan-catatan dari hasil membaca dan menelaah aktivitas psikis dalam novel Pasung Jiwa karya Okky Madasari. Teknik analisis data dalam penelitian ini adalah teknik pembacaan. Adapun maksud dari teknik pembacaan ini untuk menjembatani teks karya sastra dengan pikiran pembaca dalam hal ini peneliti, guna menangkap maksud yang terdapat dalam karya tersebut.

Teknik analisis data di atas dapat dijabarkan sebagai berikut.

a. Membaca kembali novel Pasung Jiwa karya Okky Madasari secara kritis.

b. Mengidentifikasi data yang berhubungan dengan sub masalah.

c. Mengklasifikasikan data sesuai dengan permasalahan di dalam penelitian, yaitu tentang gejala kognitif, gejala afektif, gejala konatif, dan gelaja campuran tokoh utama dalam novel Pasung Jiwa karya Okky Madasari.

d. Menganalisis data yang berkaitan dengan aktivitas psikis tokoh utama dalam novel Pasung Jiwa karya Okky Madasari.

e. Menyimpulkan hasil akhir yang telah didapatkan sesuai dengan rumusan masalah.

f. Menganalisis pengimplementasian aspek aktivitas psikis tokoh utama dalam novel Pasung Jiwa karya Okky Madasari terhadap rencana pelaksanaan pembelajaran.

\section{HASIL PENELITIAN}

Data yang dianalisis dalam penelitian ini berupa kutipan-kutipan (kata, frasa, kalimat naratif maupun dialog), yang berkaitan dengan aktivitas psikis yang dicerminkan dalam novel Pasung Jiwa karya Okky Madasari. Data tersebut diklasifikasikan sesuai masalah yang ditemukan berupa gejala kognitif, gejala afektif, gejala konatif dan gejala campuran. Data dalam penelitian ini adalah semua kutipan tentang aktivitas psikis yang terdapat dalam novel Pasung Jiwa karya Okky Madasari.

a. Gejala Pengenalan atau Kognitif

Adapun penggunaan gejala kognitif yang didasari oleh perhatian dalam novel Pasung Jiwa karya Okky Madasari dapat diperhatikan pada data-data berikut ini.

Aku mencintainya lebih dari apa pun. Aku senang berada di dekatnya. Aku senang memperhatikannya, melihat tingkahnya, mengamati senyumnya. Aku memperhatikan setiap pakaian yang dikenakannya. Baju-baju warna merah jaтu, sepatu-sepatu lucu. Kini ada sesuatu yang bisa ku ingat selain piano dan nada-nada itu: Melati. Nama yang indah, bukan? (Okky, 2015:16).

Kutipan di atas menceritakan Sasana yang mencintai adiknya, Melati. Ia senang berada di dekat Melati. Ia senang memperhatikan adiknya. Ia suka memperhatikan tingkah Melati dan mengamati senyumnya. Ia juga memperhatikan setiap pakaian yang dikenakan adiknya, baju-baju warna merah jambu, dan sepatu-sepatu lucu. Kini ada sesuatu yang bisa diingat Sasana selain piano dan nada-nada itu: Melati nama yang indah menurut Sasana.

Berdasarkan uraian di atas, dapat diketahui bahwa perilaku Sasana akibat dari stimulus yaitu Sasana mencintai Melati lebih dari apa pun. Maka respon yang dilakukan Sasana yaitu dia senang memperhatikan Melati, melihat tingkahnya, mengamati senyumnya. Dia juga memperhatikan setiap pakaian yang dikenakan Melati. 


\begin{tabular}{l} 
Stimulus \\
\begin{tabular}{|l|l|} 
Sasana mencintai adiknya \\
Melati, lebih dari apa pun.
\end{tabular} \\
\hline
\end{tabular}

\section{b. Gejala Perasaan dan Emosi atau Afektif}

Gejala afektif merupakan bagian dari kegiatan psikis yang berkenaan dengan perasaan dan emosi manusia. Adapun penggunaan gejala afektif yang didasari oleh perasaan dalam novel Pasung Jiwa karya Okky Madasari dapat diperhatikan pada data-data berikut ini.

Aku menatap matanya. Lembut dan hangat. Tak seperti perawat lain yang kala menatap kami seperti hendak menelan kami bulat-bulat. Ia tersenyum. Membuatku merasa malu karena tertangkap mata sedang mengukur-ukur tiap sudut wajahnya (Okky, 2015:131).

Kutipan di atas menceritakan tentang Sasana yang meperhatikan perawat. Ia menatap matanya. Lembut dan hangat. Sasana merasa perawat tersebut beda dengan perawat yang lain setipa menatap pasien RSJ seperti hendak menelan mereka bulat-bulat. Perawat tersebut tersenyum. Membuat Sasana merasa malu karena tertangkap mata sedang mengukur-ukur tiap sudut wajahnya.

Berdasarkan uraian di atas, dapat diketahui bahwa perilaku Sasana akibat dari stimulus yaitu ia menatap mata si perawat. Lembut dan hangat. Perawat tersebut berbeda dengan perawat yang lainnya. Ia tersenyum. Maka respon yang ditunjukkan yaitu Sasana merasa malu karena tertangkap mata sedang mengukur-ukur tiap sudut wajah perawat tersebut.

Stimulus

Sasana menatap mata si perawat. Lembut dan hangat. Ia tersenyum pada Sasana.

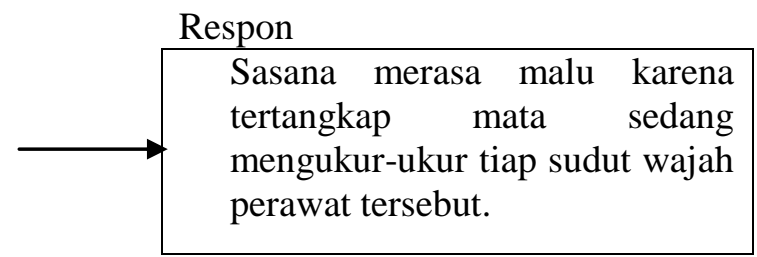

c. Gejala Kemauan atau Konatif

Sumanto mengatakan kemauan merupakan salah satu fungsi hidup kejiwaan manusia yang dapat diartikan sebagai aktifitas psikis yang mengandung usaha aktif dan berhubungan dengan pelaksanaan suatu tujuan yang menjadi titik akhir dari gerakan yang menuju pada suatu arah. Dalam istilah seharihari, kemauan dapat disamakan dengan kehendak atau hasrat yang merupakan fungsi jiwa untuk dapat mencapai sesuatu. Adapun penggunaan gejala konatif yang didasari oleh refleks dalam novel Pasung Jiwa karya Okky Madasari dapat diperhatikan pada data-data berikut ini.

Aku belum selesai menyanyikan satu lagu saat seorang laki-laki itu meremas tonjolan dadaku. Ia melakukannya sambil tertawa. Teman-temannya yang melihat pun ikut terbahak. Bau minuman keras menyengat ketika laki-laki itu mendekat. Mereka semua sedang mabuk. Remasan yang begitu cepat. Meninggalkan perasaan ganjil, antara rasa kehilangan dan rasa dipermalukan. Pikranku tak mampu segera menerjemahkan apa yang kurasakan. Selama beberapa saat aku hanya bengong, tak bereaksi apa-apa. Tapi kemudian ketika tangan itu kembali meremas tonjolan dadaku, tangan-tanganku tak bisa lagi dikendalikan. Dengan cepat pukulanku mengenai wajah laki-laki itu (Okky, 2015:61).

Kutipan di atas menceritakan tentang Sasana yang sedang mengamen di seputar alun-alun. Ia ngamen hampir subuh. Saat itu datang lima orang laki-laki. Belum selesai menyanyikan satu lagu salah seorang lelaki itu meremas tonjolan dada Sasana sambil tertawa. Teman-temannya yang melihat pun ikut 
terbahak. Mereka semua sedang mabuk. Perbuatan itu membuat Sasana merasa kehilangan dan dipermalukan. Selama beberapa saat Sasana hanya bengong, tak bereaksi apa-apa. Tapi kemudian ketika tangan itu kembali meremas tonjolan dada Sasana, tangan-tangannya tak lagi bisa dikendalikan. Dengan cepat pukulannya mengenai wajah laki-laki tersebut.

Stimulus

Seorang laki-laki
tonjolan dada Sasana.

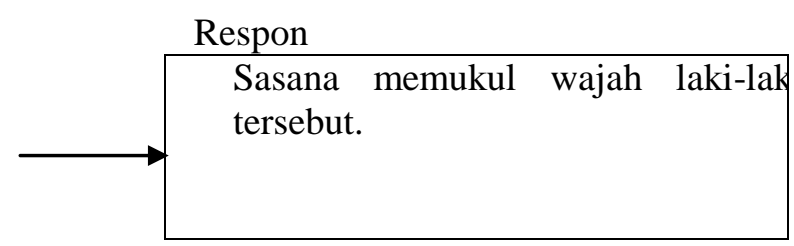

\section{d. Gejala Campuran}

Gejala campuran atau yang biasa juga disebut sebagai gejala kombinasi merupakan campuran dari ketiga gejala yang telah dipaparkan sebelumnya. Adapun penggunaan gejala campuran yang didasari oleh perhatian dalam novel Pasung Jiwa karya Okky Madasari dapat diperhatikan pada data-data berikut ini.

Aku mencintainya lebih dari apa pun. Aku senang berada di dekatnya. Aku senang memperhatikannya, melihat tingkahnya, mengamati senyumnya. Aku memperhatikan setiap pakaian yang dikenakannya. Baju-baju warna merah jaтu, sepatu-sepatu lucu. Kini ada sesuatu yang bisa ku ingat selain piano dan nada-nada itu: Melati. Nama yang indah, bukan? (Okky, 2015:16).

Kutipan di atas menceritakan Sasana yang mencintai adiknya, Melati. Ia senang berada di dekat Melati. Ia senang memperhatikan adiknya. Ia suka memperhatikan tingkah Melati dan mengamati senyumnya. Ia juga memperhatikan setiap pakaian yang dikenakan adiknya, baju-baju warna merah jambu, dan sepatusepatu lucu. Kini ada sesuatu yang bisa diingat Sasana selain piano dan nada-nada itu: Melati nama yang indah menurut Sasana.

Berdasarkan uraian di atas, dapat diketahui bahwa perilaku Sasana akibat dari stimulus yaitu Sasana mencintai Melati lebih dari apa pun. Maka respon yang dilakukan Sasana yaitu dia senang memperhatikan Melati, melihat tingkahnya, mengamati senyumnya. Dia juga memperhatikan setiap pakaian yang dikenakan Melati.

Stimulus

Sasana mencintai adiknya Melati, lebih dari apa pun.

$\longrightarrow \quad \begin{aligned} & \text { Respon } \\ & \text { Sasana senang melihat tingkah } \\ & \text { Melati. }\end{aligned}$

\section{SIMPULAN}

Berdasarkan hasil analisis dan pembahasan yang telah diuraikan, maka dapat ditarik kesimpulan mengenai aktivitas psikis tokoh utama dalam novel Pasung Jiwa karya Okky Madasari. Kesimpulan hasil penelitian ini didasarkan pada rumusan masalah, tujuan, dan hasil analisis data penelitian. Sehubungan dengan itu, terdapat beberapa temuan yang berkaitan dengan gejala pengenalan atau kognitif, gejala perasaan atau afektif, gejala kemauan atau konatif, gejala campuran tokoh utama dan implementasi aktivitas psikis tokoh utama dalam novel Pasung Jiwa karya Okky Madasari terhadap rencana pembelajaran Bahasa dan Sastra Indonesia.

a. Gejala kognitif yang ditemukan dalam novel Pasung Jiwa karya Okky Madasari adalah perhatian, pengamatan, tanggapan, fantasi, ingatan, pikiran, dan intuisi.

b. Gejala afektif yang ditemukan dalam novel Pasung Jiwa karya Okky Madasari adalah perasaan, affek dan stemming, suasana hati, simpati dan empati.

c. Gejala konatif yang ditemukan dalam novel Pasung Jiwa karya Okky Madasari adalah refleks, kebiasaan, nafsu, keinginan, dan kecendrungan. 
d. Gejala campuran yang terdapat dalam novel Pasung Jiwa karya Okky Madasari adalah perhatian, kelelahan, dan sugesti.

e. Implementasi aktivitas psikis tokoh utama dalam novel Pasung Jiwa karya Okky Madasari terhadap rencana pembelajaran yang disesuaikan dengan indikator pembelajaran dengan keterbacaan teks yaitu siswa membaca novel Pasung Jiwa, dapat diterapkan pada pembelajaran bahasa dan sastra Indonesia di sekolah. Disesuaikan dengan kurikulum yang berlaku yaitu KTSP, dapat diimplementasikan pada sekolah tingkat SMA kelas XI semester satu, pada Standar Kompentensi (SK) Membaca: 7. Memahami berbagai hikayat, novel Indonesia/terjemahan. Kompetensi Dasar (KD) 7.2 Menganalisis unsur-unsur instrinsik dan unsur ekstrinsik novel Indonesia. Media yang digunakan adalah media bahan cetak berupa teks novel, metode yang digunakan adalah model Cooperative Two Stay Two Stray dan penilaian yang digunakan berupa penugasan yaitu berupa soal esai.

\section{Daftar Pustaka}

Emzir dan Rohman. 2015. Teori dan Pengajaran Sastra. Jakarta: RajaGrafindo Persada.

Endraswara, Suwardi. 2013. Meodelogi Penelitian Sastra. Yogyakarta: CAPS (Center For Academic Publishing Service).

Minderop, Albertine. 2013. Psikologi Sastra. Jakarta: Yayasan Pustaka Obor Indonesia.

Moleong. 2014. Metodelogi Penelitian Kualitatif. Bandung: PT Remaja Rosdakarya.

Nurgiyantoro, Burhan. 2010. Penilaian Pembelajaran Bahasa. Yogyakarta: BPFE-Yogyakarta.

Nurgiyantoro, Burhan. 2015. Teori Pegkajian Fiksi. Yogyakarta: Gadjah Mada University Press

Ratna, Nyoman Kutha. 2013. Teori, Metode, dan Teknik Penelitian Sastra. Yogyakarta: Pustaka Pelajar.

Wicaksono, Andri. 2014. Pengkajian Pros Fiksi. Yogyakarta: Grudhawaca. 